\title{
Coarctation of the Aorta: Its Importance for Pediatricians and Cardiologists
}

\author{
Gesmar Volga Haddad Herdy \\ Universidade Federal Fluminense, Niterói, RJ - Brazil
}

Coarctation of the aorta is a congenital defect that affects $5-8 \%$ of live births, with different degrees of severity. It may remain unnoticed throughout childhood or, in contrast, progress to heart failure and cardiogenic shock. ${ }^{1-3}$ The most common location for coarctation of the aorta is near the ductal remnant and left subclavian artery. ${ }^{4}$

The main clinical signs of coarctation of the aorta are heart murmur, diminished pulses in lower extremities, arterial hypertension, left ventricular hypertrophy. It is commonly associated with a bicuspid aortic valve. In adults, in addition to hypertension with increased systemic vascular resistance, retinal arteriolar abnormality and lower extremity claudication may also occur. ${ }^{5}$

The first surgical treatment for coarctation of the aorta was proposed by Craford in 1945 at Mayo Clinic. ${ }^{6}$ The surgery remains the gold standard treatment, with good results. In 1982, an endovascular treatment was proposed in an experimental study, the balloon angioplasty. ${ }^{7}$ Since then, several reports have shown positive results of this less invasive technique, including in children. A long-term follow-up is mandatory, due to potential complications after open surgeries and angioplasties, such as recurrent coarctation, aneurysm or pseudoaneurysm and valve dysfunction. ${ }^{5,8}$ In a multicenter study, Erben et al. ${ }^{5}$ reported the cases of 93 adult patients undergoing endovascular treatment. Thirty-two patients were newly diagnosed, 61 were endovascular reintervention (50 recurrent coarctation and 11 aneurysmal degeneration). Endovascular treatment was mostly performed using balloon-expandable and stent grafts. Freedom from reintervention at 5 years was

\section{Keywords}

Heart Defects, Congenital; Aortic Coarctation/surgery; Shock, Cardiogenic; Hypetrophy, Left Ventricular.
85\%. ${ }^{5}$ Between 1946 and 2005, 819 patients with isolated coarctation of the aorta underwent surgical repair at the Mayo Clinic. ${ }^{9}$ End-to-end anastomosis $(n=632)$ was performed in most cases, followed by other techniques including patch angioplasty and interposition grafting. Long-term survival was decreased, and many patients required reoperation, especially when the primary operative repair was performed in patients younger than 20 years old. Children younger than 9 years of age at repair had lower complications. ${ }^{9}$

In Brazil, Coimbra et al. ${ }^{10}$ reported the results of angioplasty in 10 children aged $51.1 \pm 30.8$ years weighing less than $25 \mathrm{~kg}$, eight of them with recurrent coarctation and two with native coarctation. Angioplasty was performed using stents or balloons. ${ }^{10}$ In the study by Chamié et al., ${ }^{11}$ covered stent implantation was performed in 14 patients (adults and children), 10 with native coarctation and four as a second device. Patients were followed for $51.7 \pm 29.8$ months, without complications or deaths. ${ }^{11}$

In a study conducted in Australia involving 140 children with coarctation of aorta, 112 underwent surgical or endovascular repair as follows: end-toend anastomosis $(n=43)$, subclavian flap aortoplasty $(n=28)$, percutaneous repair $(n=6)$ and interposition tube grafts $(n=4)$. During a follow-up of 20 years, patients with end-to-end repair had lower rates of recoarctation or aneurysms. ${ }^{12}$ In a Canadian study, Rodes-Cabau et al. ${ }^{13}$ compared surgical repair versus transcatheter treatment in 80 patients of different ages, including children under one year of age. Fifty patients underwent percutaneous angioplasty, with stent implantation in 19 of them. The other 30 patients underwent surgical repair. Angioplasty reduced morbidity and hospitalization length but was associated with a higher rate of reintervention and aneurysm occurrence. ${ }^{13}$

Mailing Address: Gesmar Volga Haddad Herdy

Universidade Federal Fluminense - Hospital Universitário Antonio Pedro - Rua Marques de Paraná, 303. Postal Code: 24033-900, Niterói, Rio de Janeiro, RJ Brazil

E-mail: gesmarhaddad@gmail.com 
The American Heart Association statement recommends that percutaneous transcatheter interventions should be performed, whenever possible, for treatment of congenital repair, including coarctation and recoarctation, regardless of age. ${ }^{14}$

The study by Barreto et al., ${ }^{15}$ published in this issue, describes the outcome of 72 patients with coarctation of aorta, who underwent end-to-end anastomosis in a single center, during a 20-year follow-up. Surgery was performed at different ages (0.1-27 years). In a mean follow-up of 5.8 years, the most common complications were arterial hypertension (39.2\%) and recoarctation (28.6\%). ${ }^{15}$ These results were similar to previous studies on surgical repair of coarctation of the aorta.

\section{References}

1. Anderson RH, Baeker EJ, Mackartney FJ, Rigby ML, Shinebourne EA, Tynan M, editores. Paediatric cardiology. 2nd ed. London: Churchil Lingstone; 2002.

2. Samanek M, Voriskova M. Congenital heart disease among 815.569 children born between 1980-1990 and their 15 year survival. a prospective Bohemian survival study. Pediatr Cardiol. 1999;20(6):411-7.

3. Herdy GVH, Araújo e Silva. Cardiopatias congênitas. In: Dutra A. Medicina Neonatal. 2a ed. Rio de Janeiro: Rubio; 2016. p. 116-25.

4. Warnes CA, Williams RC, Bashore TM, Child JS, Connolly HM, Dearani JA, et al. ACC/AHA 2008 guidelines for the management of adults with congenital heart disease: a report of the American College of Cardiology/ American Heart Association Task Force on Practice Guidelines (Writing Committee to Develop Guidelines on the Management of Adults With Congenital Heart Disease). Developed in Collaboration With the American Society of Echocardiography, Heart Rhythm Society, International Society for Adult Congenital Heart Disease, Society for Cardiovascular Angiography and Interventions, and Society of Thoracic Surgeons. J Am Coll Cardiol. 2008;52(23):e143-e263.

5. Erben $Y$, Oderich GS, Verhagen HJM, Witsenburg M, van den Hoven AT, Debus ES, et al. Multicenter experience with endovascular treatment of aortic coarctation in adults. J Vasc Surg. 2019;69(3):671-9.

6. Craford C, Nylin G. Congenital coarctation of the aorta and its surgical treatment. J Cardiovasc Surg. 1945;14:347-61.

7. Lock JE, Niemi T, Burke BA, Einzig S, Castaneda-Zuniga WR. Transcutaneous angioplasty of experimental aortic coarctation. Circulation. 1982;66(6):1280-6.
In conclusion, pediatricians should carefully examine newborns and infants for the presence of decreased pulse in lower extremities and systolic heart murmurs, which are the main signs of malformation at this age, for an early diagnosis of coarctation of aorta. In adolescents and adults, treatment for this condition may lead to higher morbidity and recoarctation rates. Studies have shown that a lifetime follow-up of patients with coarctation of the aorta undergoing open surgical treatment or percutaneous intervention is strongly recommended to treat potential complications. In general, although percutaneous procedure is associated with lower morbidity and lower hospitalization length, it may lead to more complications.

8. Torok RB, Campbell MJ, Fleming GA, Hill KD. Coarctation of the aorta: management from infancy to adulthood. World J Cardiol. 2015;7(11):765-75.

9. Brown ML, Burkhart HM, Connoly HM, Dearani JA, Cetta F, Li Z, et al. Coarctation of the aorta: lifelong surveillance is mandatory following surgical repair. J Am Coll Cardiol. 2013;62(11):1020-5.

10. Coimbra G, Duarte EV, Kajita LJ, Lemos P, Arrieta R. Aortic coarctation in children weighing less than $25 \mathrm{~kg}$ : percutaneous axillary artery approach. Rev Bras Cardiol Invasiva. 2014;22(3):271-4.

11. Chamié F, Chamié D, Simões LCN, Silva RM. Use of covered stents in the treatment of aorta coarctation. Rev Bras Cardiol Invasiva. 2015;23(2):139-44.

12. Choudhary P, Canniffe C, Jackson DJ, Tanous D, Walsh K, Celermajer DS. Late outcome in adults with coarctation of the aorta. Heart. 2015;101(15):1190-5.

13. Rodes-Cabau J, Miró J, Dancea A, Ibrahim R, Piette E, Lapierre C, et al. Comparison of surgical and transcatheter treatment of native coarcation of the aorta in patients $\geq$ one year old. The Quebec Native Coarctation of the Aorta Study. Am Heart J. 2007;154(1):186-92.

14. Feltes TF, Bacha E, Beekman RH 3rd, Cheatham JP, Feinstein JA, Gomes AS, et al. Indications for cardiac catheterization and intervention in pediatric cardiac disease: a scientific statement from the American Heart Association. Circulation. 2011;123(22):2607-52.

15. Barreto J, Roda J, Germano AW, Damião AP, Quinaglia T. Coarctation of the aorta: a case series from Tertiary Care Hospital. Int J Cardiovasc Sci. 2020;33(1):3-11. 